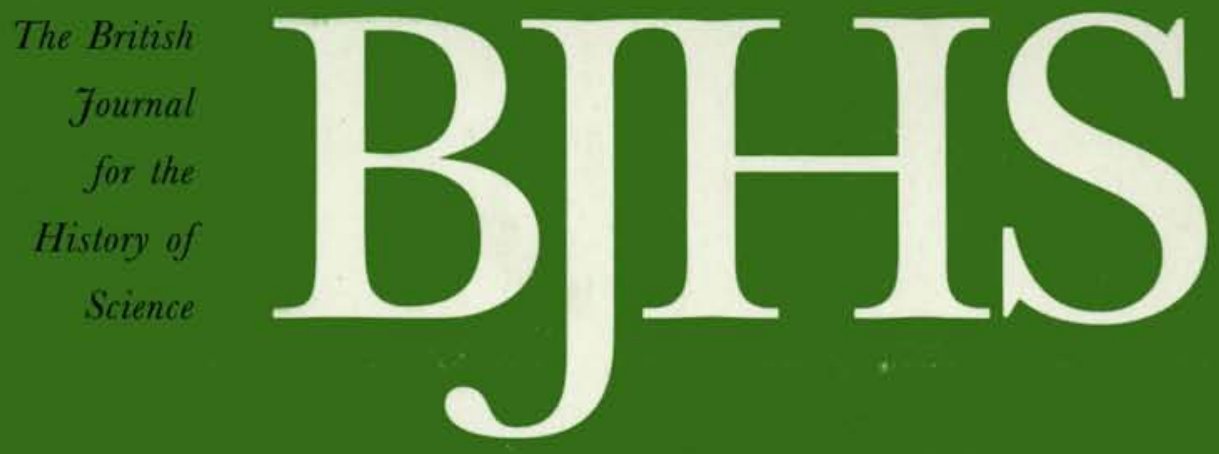

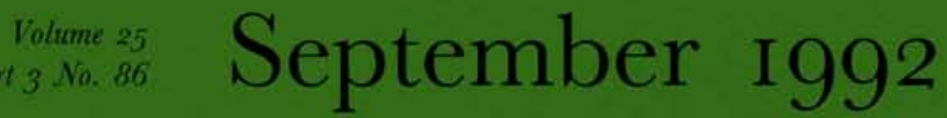

ISSN Published for The British Socicty for the History of Science $0007-0874$ by Cambridge University Press 
EDITORIAL BOARD

John Brooke Editor

Dept. of History

Furness College

University of Lancaster

Lancaster LAl 4YG

\section{Robert Bud}

Science Museum

South Kensington

London SW7 2DD

Tore Frangsmyr

Office for History of Science

Uppsala University

Box 256, S-751 05 Uppsala

Sweden

Owen Hannaway

Dept. of History of Science

The Johns Hopkins University

Gilman Hall

Baltimore, Maryland 21218

USA
John Henry

(Book Review Editor)

Science Studies Unit

University of Edinburgh

21 Buccleuch Place

Edinburgh EH8 9LN

Michael Hunter

Dept. of History

Birkbeck College

University of London

London WClE 7HX

Ludmilla Jordanova

Dept. of History

University of Essex

Wivenhoe Park

Colchester CO4 3SQ

David Lindberg

Dept. of History of Science

Helen C. White Hall 4143

University of Wisconsin

Madison, Wisconsin 53706

USA
Giuliano Pancaldi

Dept. of Philosophy

University of Bologna

Via Zamboni 38

40126 Bologna

Italy

Michael Shortland

Dept. of History and

Philosophy of Science

University of Sydney

Sydney NSW 2006

Australia

Charles Webster

All Souls College

Oxford OX1 4AL

Richard Yeo
Dept. of Humanities
Griffith University
Nathan
Brisbane
Queensland
Australia 4111

Contributions are welcome and should be sent to the Editor. They are considered on the understanding that they are unpublished and are not on offer to another journal. Two copies should be submitted, typed in double-spacing with a margin on A4 or American quarto paper. Include an abstract of 150-200 words. Quotations when long should be inset; when short, in single quotation marks. Spelling should follow the Oxford English Dictionay, and arrangement H. Hart, Rules for Compositors, Oxford, many edns. Be clear and consistent.

All papers should be rigorously documented, with references to primary and secondary sources typed separately from the text in double spacing, and numbered consecutively. Cite as follows:

1 B. Smetov and D. Blogski. Chemisty in the Eighteenth Century, 2nd edn (tr. R. Roe), 5 vols., Edinburgh, 1896-1914, iii, 237-8. Only cite the publisher for good reason.

$2 \mathrm{~J}$. Doe, 'Searching for gravity waves', in The History of Physics (ed. A. Burn and Z. Trent), Oxford, 1982, 22-9 (subsequent references may be written: 3 Doe, op. cit. (2), 23-4).

4 N. Brown. 'Developments of the cathode ray', Joumal of Physics (1972), 7, 31-5. Abbreviated journal titles may be given where these are in common use.

Standard works such as $D N B, D S B$, may be cited thus. For these, cite University Microfilm order number, or at least Dissertations Abstract number. Line drawings should be drawn boldly in black ink on stout white paper, feint-ruled graph paper or tracing paper. Photographs should be glossy prints of good contrast and well matched for total range. The place of an illustration should be indicated in the margin of the text and the text reference given. Each illustration must carry the name of the author and the article, its number, and a caption. Xerox copies may be sent when the article is first submitted for consideration.

(c) British Society for the History of Science. The British Society for the History of Science retains copyright for all articles published: it is the author's responsibility to secure any necessary permission for publication. Single copies of articles may be made for research or private study without further ado. Permission to make multiple copies should be obtained from the Society. Authors will receive twenty-five offprints of articles free. The Editor cannot accept responsibility for loss of a typescript, but will take every care of it; typescripts are not normally returned to authors. In all matters concerning the publication of the article, the Editor's decision is final.

Subscriptions: The British Joumal for the History of Science (ISSN: 0007-0874) is published quarterly in March, June, September and December. The subscription price of Volume 25, 1992, is $£ 68$ net (USA and Canada LS \$125) post free; single parts cost $£_{1} 19$ net (USA and Canada US \$33) plus postage. Four parts form a volume. Orders, which must be accompanied by payment, may be sent to any bookseller, subscription agent or to the publisher: Cambridge University Press, The Edinburgh Building, Shaftesbury Road, Cambridge CB2 2RU or in the USA and Canada to Cambridge University Press, The Journals Department, 40 West 20th Street, New York, NY 10011-4211, USA. Copies of the journal for subscribers in the USA and Canada are sent by air to New York to arrive with minimum delay. Second-class postage paid at New York, NY and at additional mailing offices. POSTMASTER: send address changes in USA and Canada to The British Joumal for the History of Science, Cambridge University Press, 110 Midland Avenue, Port Chester NY 10573-9864. 